\title{
Limnological aspects of an Apennine shallow lake
}

\author{
A. Ruggiero ${ }^{1}$, A.G. Solimini ${ }^{2}$, G. Carchini ${ }^{1}$ \\ ${ }^{1}$ Laboratorio di Ecologia Sperimentale e Acquacoltura, Dipartimento di Biologia, Università degli Studi di Roma «Tor Vergata», Via della \\ Ricerca Scientifica, 00133 Roma, Italia. E-mail : antonio.ruggiero@uniroma2.it \\ ${ }^{2}$ In land and Marine Waters Institute for Environment and Sustainability, European Commission, Joint Research Center, I - 21020 Ispra, VA, \\ Italy.
}

We present the results of a four-years monitoring program of Lake Duchessa, a small shallow subalpine lake situated at 1788 m a.s.l. in central Apennines (Italy). From 1997 to 2000, during snow free periods, we regularly measured conductivity, pH, macrophyte cover and water transparency. Contemporarily, 4 water samples were collected to determine nutrient $\left(\mathrm{NH}_{3}-\mathrm{N}, \mathrm{NO}_{2}-\right.$ $\mathrm{N}, \mathrm{NO}_{3}-\mathrm{N}$ and $\mathrm{PO}_{4}-\mathrm{P}$ ) and phytoplanktonic chlorophyll $a$ concentrations. Taxonomic compositions of aquatic macrophytes, zooplankton and macroinvertebrates were also determined. Inter- and intra-annual variation of water chemistry and phytoplankton biomass were addressed. Lake Duchessa showed some limnological aspects proper to lowland eutrophic situations due to livestock grazing in the watershed pastures and watering in the lake. In particular, nutrient concentration and phytoplankton biomass reached extremely high values, and lake community was relatively poor. However, despite the high nutrient loading, phytoplankton biomass collapsed in August 1997. In the same occasion, lake water became transparent and remained clear until the end of 1999. The occurrence of this clear water phase and its surprising span may be related to the reduction of tench population (due to a natural fish kill observed during the study) and to the extension of Potamogeton pectinatus L. and Myriophyllum spicatum L. cover. Our results support early observations that water transparency (i.e. environmental quality) of eutrophic shallow lakes can be improved also when nutrient loading is not reduced. Many of the Apennine lakes and ponds situated at high altitudes show conditions similar to those of Lake Duchessa. Therefore this study highlights the ecological processes to be considered in a reliable management of these freshwater systems.

Keywords : eutrophication, mountain, clear water phase, Lake Duchessa, Lazio

\section{Introduction}

Small freshwater systems add significant biodiversity value to a region (Collinson et al. 1995, King et al. 1996, Di Sabatino et al. 2003). This is particularly true in the central Apennines over 1000 a.s.l. where permanent surface water is scarce and aquatic life is mainly supported by small lakes and permanent ponds. Accordingly, it is also known that these precious water bodies show distinctive communities including nationally rare species (Stella 1988, Mura 1993, Cianficconi et al. 1994, Mura 1996, Di Giorgio \& Zuppa 1996, Mura et al., 2003). Due to their limited dimensions they are particularly sensitive to weather changes and environmental modifications. The water quality of these systems is thus of immediate concern for local authorities. Accordingly, most of them are situated within protected areas.

In central Italy, sheep, horses and cows are taken to graze on Apennine pastures during snow free seasons.
Livestock-derived excreta enter lakes and ponds either directly or after draining from their watershed. Livestock feces and urine contain large quantities of nutrients: annual estimates (kg per individual) of phosphorus and nitrogen excreted by livestock ranges from 1.5 (sheep) to 11 (horse) $\mathrm{kg} \mathrm{y}^{-1}$ and from 8.9 (sheep) to 77 (horse) $\mathrm{kg} \mathrm{y}^{-1}$ respectively (Moss et al. 1997, p. 41). They thus represent a high potential source of nutrients and a contributory factor in the eutrophication of mountain Apennine lakes and ponds. Park managers are faced with a range of problems related to eutrophication such as blooms of algae, turbid water and natural fish kills, and ask for reliable mitigating and preventative management strategies.

In general, management of water quality requires monitoring of chemical and biological factors of the water body and a knowledge of their response to land use variation and environmental change (Larson et al. 1994, Rioual 2002, Portielje \& Rijsdijk 2003). To date there have been only sporadic studies of Apennine fresh- 
water systems, therefore there is a requirement for a more systematic approach (but see Baldi 1942, Margaritora \& Usai 1983, Mura 1987, Solimini et al. 2000, Ruggiero et al. 2001, Ruggiero et al. 2003 a,b). Accordingly, little is known about their limnological aspects and possible, appropriate, management strategies. In this paper, we present the results of a four year monitoring program of the main chemical and biological factors of Lake Duchessa. This shallow lake, situated in the central Apennines at $1788 \mathrm{~m}$ a.s.l., can be considered as a representative of many lakes and ponds situated at high altitudes in this area. Data shown offer insights into the nutrient dynamics and the primary production in these systems. The aim of this paper is to individualise the ecological processes to consider in the future for the possible managing and mitigating strategies of Apennine lakes and ponds.

\section{Study area}

The Apennine mountain chain runs from the north to the south of Italy, reaching its highest altitudes in the central region with peaks between 2500 and $3000 \mathrm{~m}$ a.s.l. Here, sedimentary carbonate rocks dominate and the upper limit of the timber line ranges from 1700 to $1900 \mathrm{~m}$ a.s.l. There is an annual average of 1000-1500 $\mathrm{mm}$ of precipitation per year above $1000 \mathrm{~m}$ a.s.l. but the widespread karstic soils cause rapid losses of surface water. Lake Duchessa $\left(42^{\circ} 11^{\prime} \mathrm{N}, 13^{\circ} 20^{\prime} \mathrm{E}\right)$ is a small and shallow subalpine lake situated at $1788 \mathrm{~m}$ a.s.l. (Fig. 1, Table 1). It is, along with Lake Pilato

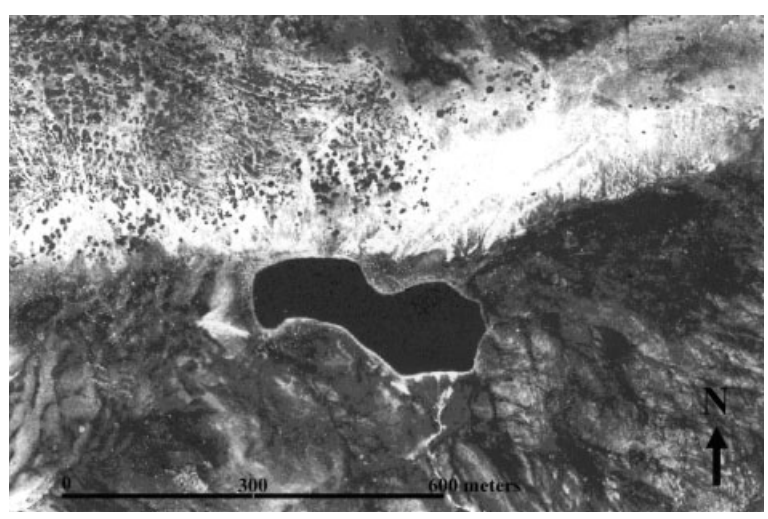

Fig. 1. Lake Duchesa and its immediate environment. White areas correspond to bare rocks ands gravels, Juniperus nana bushes are evident north to the lake where the very steep slope makes meadows to be completely absent.
Table 1. Main morphological features of Lake Duchessa. Main chemical and physical variables of its water column (calculated on the basis of a monitoring program in 2002) are also shown.

\begin{tabular}{|c|c|c|c|}
\hline Altitude (m a.s.1.) & \multicolumn{3}{|c|}{1788} \\
\hline Lake Area (ha) & \multicolumn{3}{|c|}{3.5} \\
\hline Perimeter (m) & \multicolumn{3}{|c|}{975} \\
\hline Maximum length $(E-W)(m)$ & \multicolumn{3}{|c|}{350} \\
\hline Maximum width (m) & \multicolumn{3}{|c|}{100} \\
\hline Maximum depth (m) & \multicolumn{3}{|c|}{3.5} \\
\hline Catchment Area (ha) & \multicolumn{3}{|c|}{250} \\
\hline \multirow[t]{2}{*}{ Catchment Area/Lake Area } & \multicolumn{3}{|c|}{71.4} \\
\hline & Mean & Max & Min \\
\hline Water temperature $\left({ }^{\circ} \mathrm{C}\right)$ & 11.2 & 22.4 & 0.6 \\
\hline $\mathrm{pH}$ & 8.8 & 9.5 & 7.8 \\
\hline Conductivity $\left(\mu \mathrm{S} \mathrm{cm}^{-1}\right)$ & 211 & 237 & 114 \\
\hline $\mathrm{Na}^{+}\left(\mathrm{mg} \mathrm{l}^{-1}\right)$ & 2.04 & 3.14 & 1.60 \\
\hline $\mathrm{K}^{+}\left(\mathrm{mg} \mathrm{l}^{-1}\right)$ & 4.30 & 5.40 & 2.49 \\
\hline $\mathrm{Ca}^{2+}\left(\mathrm{mg} \mathrm{l}^{-1}\right)$ & 42 & 45 & 31 \\
\hline $\mathrm{Mg}^{2+}\left(\mathrm{mg} \mathrm{l}^{-1}\right)$ & 1.56 & 1.73 & 1.34 \\
\hline Alkalinity (meq $\mathrm{l}^{-1}$ ) & 1.23 & 1.90 & 0.72 \\
\hline $\mathrm{NO}_{2}-\mathrm{N}\left(\mathrm{mg} \mathrm{l}^{-1}\right)$ & 0.006 & 0.006 & 0.005 \\
\hline $\mathrm{NO}_{3}-\mathrm{N}\left(\mathrm{mg} \mathrm{l}^{-1}\right)$ & 1.14 & 1.28 & 1.00 \\
\hline $\mathrm{NH}_{3}-\mathrm{N}\left(\mathrm{mg} \mathrm{l}^{-1}\right)$ & 0.36 & 1.26 & 0.06 \\
\hline $\mathrm{PO}_{4}-\mathrm{P}\left(\mathrm{mg} \mathrm{l}^{-1}\right)$ & 0.102 & 0.218 & 0.027 \\
\hline Chlorophyll $a\left(\mu \mathrm{g}^{-1}\right)$ & 3.15 & 5.52 & 1.49 \\
\hline $\mathrm{O}_{2}\left(\mathrm{mg} \mathrm{l}^{-1}\right)$ & 8.2 & 12.5 & 1.5 \\
\hline $\mathrm{DOC}\left(\mathrm{mg} \mathrm{1}^{-1}\right)$ & 15 & 25 & 11 \\
\hline
\end{tabular}

(Mura 1993), the largest lake over $1000 \mathrm{~m}$ a.s.l. in the Apennines. The lake is of glacial origin during the Pleistocene period and was later modified by karstic processes which formed two coalescent dolines. Lake water level is maintained by local precipitation and snow-melt, its area and maximum depth reach their highest values in spring (April-May). The lake freezes over in November/December and remains ice-covered for about 4-5 months. The watershed area is mainly composed of bare rocks with only small areas of meadows and Juniperus nana Willd. bushes (Petriccione 1993) (Fig. 1). The lake is located in the protected area «Riserva Naturale Parziale Montagne della Duchessa» established in 1990. During snow-free periods, a large number of sheep, cows and horses are taken to graze in the watershed pastures and allowed, by local authorities, to water in the lake (Table 2). 
Table 2 The highest $(\max )$ and the lowest (min) maximum depth (with corresponding month), the number of animals allowed (by local authorities) to water in the lake, mean values of nutrients and Chlorophyll a (Chla) (calculated on all the sampling date (=n)) and maximum macrophyte cover, are given for each year. DIN = Dissolved Inorganic Nitrogen (NO3-N + NH3-N + NO2-N), SRP = Soluble Reactive Phosphorus, n.a. $=$ not available

\begin{tabular}{|c|c|c|c|c|c|c|c|c|c|c|}
\hline \multirow[t]{2}{*}{ Year } & \multicolumn{2}{|c|}{ Max depth (m) } & \multicolumn{3}{|c|}{ Livestock (n) } & & \multirow{2}{*}{$\begin{array}{c}\mathrm{DIN} \\
\mathrm{mg} \mathrm{l}^{-1}\end{array}$} & \multirow{2}{*}{$\begin{array}{l}\text { SRP } \\
\mathrm{mg} \mathrm{l}^{-1}\end{array}$} & \multirow{2}{*}{$\begin{array}{l}\text { Chla } \\
\mu \mathrm{g} \mathrm{l}^{-1}\end{array}$} & \multirow{2}{*}{$\begin{array}{c}\text { Macrophyte } \\
\text { cover } \%\end{array}$} \\
\hline & $\max$ & $\min$ & cows & sheep & horses & & & & & \\
\hline \multirow[t]{2}{*}{1997} & $\begin{array}{c}3.50 \\
\text { (May) }\end{array}$ & $\begin{array}{c}0.20 \\
\text { (October) }\end{array}$ & 88 & 756 & 91 & $\begin{array}{c}\text { Mean } \\
(\mathrm{SE})\end{array}$ & $\begin{array}{c}2.5 \\
(0.3)\end{array}$ & $\begin{array}{c}0.21 \\
(0.06)\end{array}$ & $\begin{array}{l}218.85 \\
(98.32)\end{array}$ & 50 \\
\hline & & & & & & $\mathbf{n}$ & 10 & 10 & 10 & \\
\hline \multirow[t]{2}{*}{1998} & $\begin{array}{c}1.35 \\
\text { (May) }\end{array}$ & $\begin{array}{c}0.20 \\
\text { (September) }\end{array}$ & 162 & 627 & 81 & $\begin{array}{c}\text { Mean } \\
(\mathrm{SE})\end{array}$ & $\begin{array}{c}1.4 \\
(0.4)\end{array}$ & $\begin{array}{c}0.27 \\
(0.11)\end{array}$ & $\begin{array}{c}51.21 \\
(19.29)\end{array}$ & 80 \\
\hline & & & & & & $\mathrm{n}$ & 5 & 5 & 5 & \\
\hline \multirow[t]{2}{*}{1999} & $\begin{array}{c}3.50 \\
\text { (May) }\end{array}$ & $\begin{array}{c}0.30 \\
\text { (October) }\end{array}$ & 263 & 800 & 140 & $\begin{array}{c}\text { Mean } \\
(\mathrm{SE})\end{array}$ & $\begin{array}{c}1.0 \\
(0.1)\end{array}$ & $\begin{array}{c}0.18 \\
(0.05)\end{array}$ & $\begin{array}{c}7.01 \\
(2.06)\end{array}$ & 90 \\
\hline & & & & & & $\mathrm{n}$ & 11 & 11 & 11 & \\
\hline \multirow[t]{2}{*}{2000} & $\begin{array}{c}2.50 \\
\text { (May) }\end{array}$ & $\begin{array}{c}0.35 \\
\text { (August) }\end{array}$ & n.a. & n.a. & n.a. & $\begin{array}{c}\text { Mean } \\
(\mathrm{SE})\end{array}$ & $\begin{array}{c}1.8 \\
(0.3)\end{array}$ & $\begin{array}{c}0.05 \\
(0.01)\end{array}$ & $\begin{array}{c}283.54 \\
(101.02)\end{array}$ & 90 \\
\hline & & & & & & $\mathrm{n}$ & 12 & 12 & 12 & \\
\hline
\end{tabular}

\section{Material and methods}

\section{Water chemistry}

Sampling was done on a monthly basis from May 1997 to November 2000, only during snow-free periods (due to logistic constraints), with more frequent sampling (every 15 days) during the summers (JuneAugust) of 1997, 1999 and 2000. At the start of the study period we installed a staff gauge in the lake to record water depth fluctuations. During each sampling occasion water was taken from 4 sites reached with an inflatable boat. Site conductivity and pH (WTW MultiLine probe) were recorded in situ. A subsurface water sample $(20 \mathrm{~cm})$ was collected with a lake water primed dark 500-ml polyethylene bottle and were immediately stored in refrigerated boxes. At the laboratory the water samples were divided into two subsamples to determine nutrient concentration and phytoplankton biomass. The first water subsample was filtered through acid cleaned filters (Whatman GF/F 0.7- $\mu \mathrm{m}$ ) and analyzed to determine $\mathrm{NO}_{2}-\mathrm{N}, \mathrm{NO}_{3}-\mathrm{N}, \mathrm{NH}_{3}-\mathrm{N}$ and $\mathrm{PO}_{4}-\mathrm{P}$ (soluble reactive phosphorus $=\mathrm{SRP}$ ) following standard methods reported in Wetzel \& Likens (1991). Dissolved inorganic nitrogen (DIN) concentration was calculated by summing $\mathrm{NO}_{2}-\mathrm{N}, \mathrm{NO}_{3}-\mathrm{N}$ and $\mathrm{NH}_{3}-\mathrm{N}$ concentrations.

\section{Community}

At each visit macrophyte cover was visually estimated as a percentage of lake area from an elevated (c.a. $2000 \mathrm{~m}$ a.s.1.) site immediately close to the lake (1788 $\mathrm{m}$ a.s.1.). Macrophyte specimens were collected and taken to the laboratory for taxonomic classification. The macrobenthic invertebrate assemblage was sampled in July and September of 1997. The macroinvertebrates living in the lake bottom and on aquatic vegetation were sampled in two different ways. We used an Ekman grab $(15 \times 15 \times 10 \mathrm{~cm})$ with pole to collect 5 samples from the lake bottom in random locations. We used twenty cages $(15 \times 15 \times 7.5 \mathrm{~cm}$, mesh $1.2 \mathrm{~cm})$ to collect samples from the aquatic vegetation. Cages were placed in situ one week before the sampling date to avoid organisms escaping during sampling activity. At 
the sampling date cages were quickly lifted into a 0.25 $\mathrm{mm}$ mesh net, after that we rapidly cut the portion of the plant remained outside of the cage. After collection samples were washed through a $0.25 \mathrm{~mm}$ mesh in the field to reduce the associated unwanted material and taken to the laboratory. Here macroinvertebrates were separated from the substrata and fixed in $70 \%$ ethanol for later taxonomic classification. The zooplankton assemblage was sampled once in 1997 and monthly in 1998 and 1999 to account for seasonal variations in taxonomic composition. At each station water was collected with buckets and filtered through a $150 \mu \mathrm{m}$ mesh plankton net. Material retained was fixed in a $4 \%$ formalin solution and taken to the laboratory for taxonomic classification. The presence of fish and amphibia was recorded at each sampling occasion.

\section{Phytoplankton biomass and water transparency}

Phytoplankton biomass was determined as Chla concentration of filtered lake water. A volume $(0.05$ $1.00 \mathrm{~L}$ ) of lake water was passed through a $0.45 \mu \mathrm{m}$ cellulose nitrate membrane filter (Whatman) which was subsequently immersed in a $90 \%$ acetone solution (24 hours in the dark) for chlorophyll $a$ extraction. Chl $a$ concentration (uncorrected for phaeopigments) was determined spectrophotometrically $(665 \mathrm{~nm})$ (Wetzel \& Likens 1991). At each station, water transparency as Secchi depth (disk diameter $=0.25 \mathrm{~m}$ ) was measured. When the bottom was visible Secchi depth was not properly measurable and for regressional analyses only valid Secchi depths were used.

\section{Results}

\section{Water chemistry}

Lake water depth showed a well defined seasonal pattern with maximum values in the spring, soon after snow melt, and minimum values in the fall (Table 2). As a consequence, the lake area varied by about 25-30 $\%$ during each year. Conductivity (at $20^{\circ} \mathrm{C}$ ) and $\mathrm{pH}$ ranged from $122 \pm 1 \mu \mathrm{S} \mathrm{cm}^{-1}$ (10 June 2000) to $358 \pm$ $21 \mu \mathrm{S} \mathrm{cm}^{-1}$ (21 August 1997) and from $7.5 \pm 0.0$ (21 August 1997) to $10.8 \pm 0.1$ (16 August 2000) respectively and showed opposing seasonal trends (Spearman test, $\mathrm{r}=-0.417, \mathrm{p}<0.01$ ) (Fig. 2). The concentration of $\mathrm{NO}_{3}-\mathrm{N}$ ranged from $0.43 \pm 0.17 \mathrm{mg} \mathrm{l}^{-1}$ (22 June 1998) to $4.03 \pm 0.19 \mathrm{mg} \mathrm{l}^{-1}$ (22 September 2000). It showed summer minima in 1997 and 1998, was less variable in 1999 and showed an increasing trend throughout 2000 (Fig. 3). The concentration of $\mathrm{NO}_{2}-\mathrm{N}$ did not show any
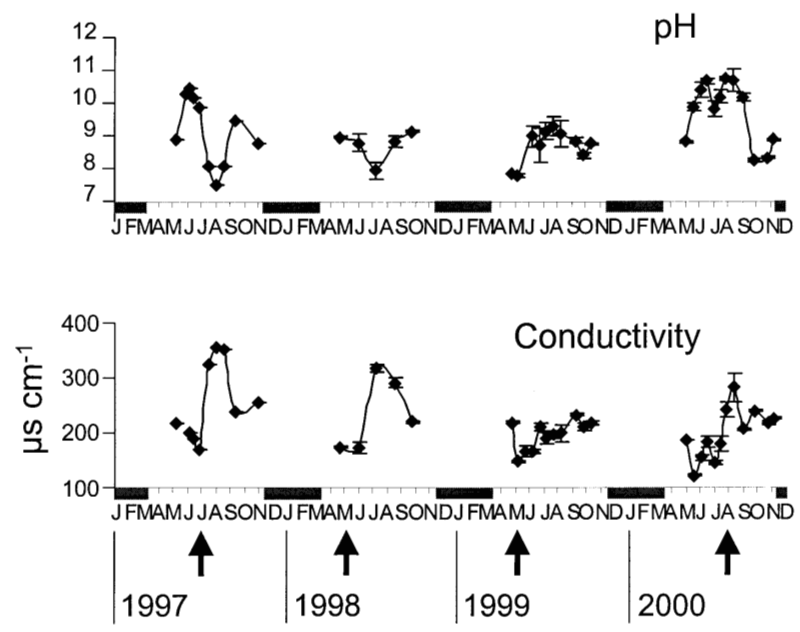

Fig. 2 Temporal patterns of $\mathrm{pH}$ and conductivity (mean $\pm \mathrm{SE}$ ) from 1997 to 2000. During ice-covered period (grey thick line), the lake was not sampled. Arrows indicate the observed fish kill events.

seasonal pattern it remaining below $0.010 \mathrm{mg} \mathrm{l}^{-1}$ throughout the study period. However high $\mathrm{NO}_{2}-\mathrm{N}$ concentrations were detected in July $\left(0.014 \pm 0.001 \mathrm{mgl}^{-1}\right)$ and November $1997\left(0.019 \pm 0.000 \mathrm{mgl}^{-1}\right)$, and in May $1999\left(0.014 \pm \mathrm{mg} \mathrm{l}^{-1}\right)$. The concentration of $\mathrm{NH}_{3}-\mathrm{N}$ showed a spring/autumn minima and summer maxima throughout the study period. It reached particularly high values (i.e. $>2.50 \mathrm{mg} \mathrm{l}^{-1}$ ) in both 1997 and 1998 . The concentration of DIN changed among years (Table 2). It decreased from 1997 to 1998, in 1999 it remained quite similar to the previous year while it increased in 2000. SRP concentration ranged from $0.011 \pm 0.003$ $\mathrm{mg} \mathrm{l}^{-1}$ (30 May 1997) to $0.587 \pm 0.022 \mathrm{mg} \mathrm{l}^{-1}$ (5 August 1997). Its seasonal pattern was similar to $\mathrm{NH}_{3}-\mathrm{N}$ (with maxima in summer) even if in 1999 it showed a sharp drop between July and August. Moreover, SRP concentrations were particularly high in the summer of 1997 and 1998 (c.a. $0.5 \mathrm{mg} \mathrm{l}^{-1}$ ). Variation of SRP concentrations was negligible in the first three years however, they were lawo in 2000 (Table 2).

\section{Community}

Five species of aquatic macrophytes were identified (Table 3). Potamogeton pectinatus L., Myriophyllum spicatum L. Eleocharis palustris (L.) Roemer et Schultes, Potamogeton perfoliatus L., Ranunculus trichophyllus Chaix. P. pectinatus and M. spicatum were 
the dominant macrophyte species, together representing the $80-90 \%$ of the macrophyte cover. In total macrophytes covered $50 \%$ of the lake area in 1997, $80 \%$ in 1998 and $90 \%$ in 1999 and 2000. The benthic macroinvertebrates assemblage included 11 families (Table 3). Coleoptera and Diptera were well represen- ted with three and four families respectively, while no mollusk families were found (for more details on quantitative data see Solimini et al. 2000). Zooplankton assemblage included 6 species of Cladocera and 4 species of Copepoda (Table 3). Among the vertebrates, Triturus carnifex Laurenti was observed in the spring

\begin{tabular}{|c|c|c|c|}
\hline & ORDER & FAMILY & SPECIES/SUBFAMILY \\
\hline Aquatic Macrophytes & $\begin{array}{l}\text { Cyperales } \\
\text { Najadales } \\
\qquad " \\
\text { Myrtales } \\
\text { Ranunculales }\end{array}$ & $\begin{array}{l}\text { Cyperaceae } \\
\text { Potamogetonaceae } \\
\qquad \\
\text { Haloragaceae } \\
\text { Ranunculaceae, }\end{array}$ & $\begin{array}{l}\text { Eleocharis palustris (L.) Roemer et Schultes } \\
\text { Potamogeton pectinatus L. } \\
\text { Potamogeton perfoliatus L. } \\
\text { Myriophyllum spicatum L. } \\
\text { Ranunculus trichophyllus Chaix }\end{array}$ \\
\hline Zooplankton & $\begin{array}{r}\text { Cladocera } \\
" \\
" \\
" \\
" \\
\text { Copepoda } \\
" \\
\text { Copepoda }\end{array}$ & $\begin{array}{r}\text { Daphniidae } \\
\qquad " \\
" ~ \\
\text { " } \\
\text { Chydoridae } \\
\text { Cyclopoida } \\
\text { " } \\
\text { Calanoida }\end{array}$ & $\begin{array}{l}\text { Ceriodaphnia reticulata (Jurine) } \\
\text { Ceriodaphnia dubia Richard } \\
\text { Simocephalus vetulus (O. F. Muller) } \\
\text { Daphnia rosea Sars } \\
\text { Daphnia obtusa Kurz } \\
\text { Chydorus sphaericus (O. F. Muller) } \\
\text { Eucyclops macruroides (Lilljeborg) } \\
\text { Eucyclops serrulatus (Fischer) } \\
\text { Acanthocyclops viridis viridis (Jurine) } \\
\text { Diaptomus sp. }\end{array}$ \\
\hline Macroinvertebrates & $\begin{array}{l}\text { Seriata } \\
\text { Tubificida } \\
\text { Diptera " } \\
\text { Heteroptera } \\
\text { Odonata } \\
\text { Coleoptera } \\
\qquad "\end{array}$ & $\begin{array}{l}\text { Tricladidae } \\
\text { Naididae } \\
\text { Tubificidae } \\
\text { Chironomidae } \\
\text { Muscidae } \\
\text { Corixidae } \\
\text { Hebridae } \\
\text { Coenagrionidae } \\
\text { Dytiscidae } \\
\text { Elmidae } \\
\text { Unidentified }\end{array}$ & $\begin{array}{l}- \\
- \\
- \\
- \\
- \\
- \\
- \\
- \\
-\end{array}$ \\
\hline Vertebrates & $\begin{array}{l}\text { Cypriniformes } \\
\text { Urodela } \\
\text { Anura }\end{array}$ & $\begin{array}{l}\text { Cyprinidae } \\
\text { Salamandridae } \\
\text { Bufonidae }\end{array}$ & $\begin{array}{l}\text { Tinca tinca L. } \\
\text { Triturus carnifex Laurenti } \\
\text { Bufo bufo L. }\end{array}$ \\
\hline
\end{tabular}


of each year with hundreds of individuals in the whole lake. Tinca tinca L. (illegally introduced in the lake not more than 10 years ago) was the only fish species found in the lake. Its population was affected by a natural fish-kill during each year: in July 1997, in May 1998, in May 1999 and in August 2000. No fish kills were observed by or reported to reserve authorities before 1997. Even if tench population density was not estimated in the lake we can say that it was particularly high in 1997 when we observed many thousands of dead tench floating in the lake on the fish kill event.

\section{Phytoplanktonic biomass and water transparen-} cy

In July 1997 phytoplanktonic biomass (Chla) reached values around $900 \mu \mathrm{g} \mathrm{l}^{-1}$ however, these values sharply dropped to around $10 \mu \mathrm{g} \mathrm{l}^{-1}$ by August remaining low for the rest of the year (Fig. 4). In 1998 and $2000 \mathrm{Chl} a$ concentration showed summer maxima of $101 \pm 64 \mathrm{~g} \mathrm{~g} \mathrm{l}^{-1}$ (30 July) and $1001 \pm 38 \mathrm{~g} \mathrm{~g} \mathrm{l}^{-1}$ (22 September) respectively. In 1999 no seasonal pattern was evident with values ranging from $0.5 \pm 0.1 \mu \mathrm{g} \mathrm{l}^{-1}$ (16 June) to $24 \pm 7 \mu \mathrm{g} \mathrm{l}^{-1}$. Again annual mean of phytoplanktonic biomass was highly variable among the study years (Table 2) decreasing from 1997 to 1999, whilst in 2000 values were similar to those of 1997. Secchi depth was negatively correlated with Chla (Spearman test $\mathrm{r}=-0.648, \mathrm{P}<0.001)$. In 1999 Secchi depth decreased from spring to summer $(0.35-0.1 \mathrm{~m})$ and reached its minimum when Chl $a$ maxima values were recorded. However, in August the lake water was so clear that the bottom was visible. This clear water phase continued until the last sampling date in November. In 1998 and 1999 no Secchi depths were made as the bottom remained visible throughout the sampling period. During 2000 lake water was turbid with a Secchi depth ranging from $0.30 \mathrm{~m}$ to $0.45 \mathrm{~m}$.

\section{Discussion}

Even if remote, mountain lakes can show large and highly variable nutrient concentration (Gee \& Duigan 1993, Beaty \& Parker 1996), values detected were unusually high (for comparisons see Vass et al. 1989, Nauwerck 1994, Viaroli et al. 1994, Larson et al. 1995, Mosello et al. 1996, Duff et al. 1999, Kopacek et al. 2000, Rioual 2002). Lake Duchessa can be classified as hypereutrophic according to nutrient concentrations, Secchi transparency depths and Chlorophyll $a$ peaks (Wetzel 1983). Among the possible external source of nutrients, livestock presence in the watershed (Table 2) represents a high potential for the eutro- phication of the Lake Duchessa. Moreover, the watershed has a high composition of bare rock with scant and thin soil layers, this fact combined with a low riparian vegetative cover results in a low nutrient retention of the catchment area. Internal cycling of matter is highly significant for the water chemistry of shallow lakes (Scheffer 1998). In particular, the processes associated to sediments play a key role in nutrient availability and primary production (Liboriussen \& Jeppesen 2003, Threlkeld 1994). In Lake Duchessa a large amount of organic matter (i.e. livestock dejections, detritus of algae and macrophytes) accumulates in the sediments each year representing a significant source of nutrients.

Conductivity and $\mathrm{pH}$ values detected were relatively high but similar to those reported for other productive lakes of the Apenninic area dominated by carbonate rocks (Solimini et al. 2000, Ruggiero et al. 2003a,b). Within-year patterns of nutrient concentration are those expected for eutrophic shallow lakes (Scheffer 1998). In these lakes, maxima of SRP and $\mathrm{NH}_{3}-\mathrm{N}$ concentrations along with sharp drops of $\mathrm{NO}_{3}-\mathrm{N}$ concentration can be observed in the summer due to a high microbial activity in the muddy sediments (Kleeberg \& Kozerski 1997) and to the consequent decrease of oxygen concentration (Van Luijn et al. 1999, Carvalho 1994). Sporadic high $\mathrm{NO}_{2}-\mathrm{N}$ concentrations usually occur when a large amount of fresh and easily degradable organic matter is mineralized (Colliver \& Stephenson 2000, Leu et al. 1998, Burns et al. 1995). Accordingly, the presence of dead fishes in July 1997 and May 1999 could explain the high nitrite concentration detected in these months so as in November 1997 when a abundant degradable organic matter due to the large summer fish kill was leaky still present.

The decrease in DIN concentration in 1998 and 1999 was not due to a lower fecal derived input since livestock number actually increased in these years (Table 2 ). On the other hand, it has been shown that macrophytes reduces DIN concentration by (i) increasing direct uptake of DIN from the water column (Barko \& James 1997), (ii) supporting a higher biomass of attached periphytic algae which in turn increase nutrient uptake from the water column (Strand \& Weisner 2001) and (iii) supporting denitrifying bacteria (Meijer et al. 1994, Eriksson \& Weisner 1999). Accordingly, it is possible that the decrease in DIN concentration was related to the observed increase in macrophyte cover (Table 2). However, in 2000 with macrophytes still covering $90 \%$ of the lake area, DIN concentrations were similar to those values observed in 1997 suggesting some other regulating processes involved such as dilu- 

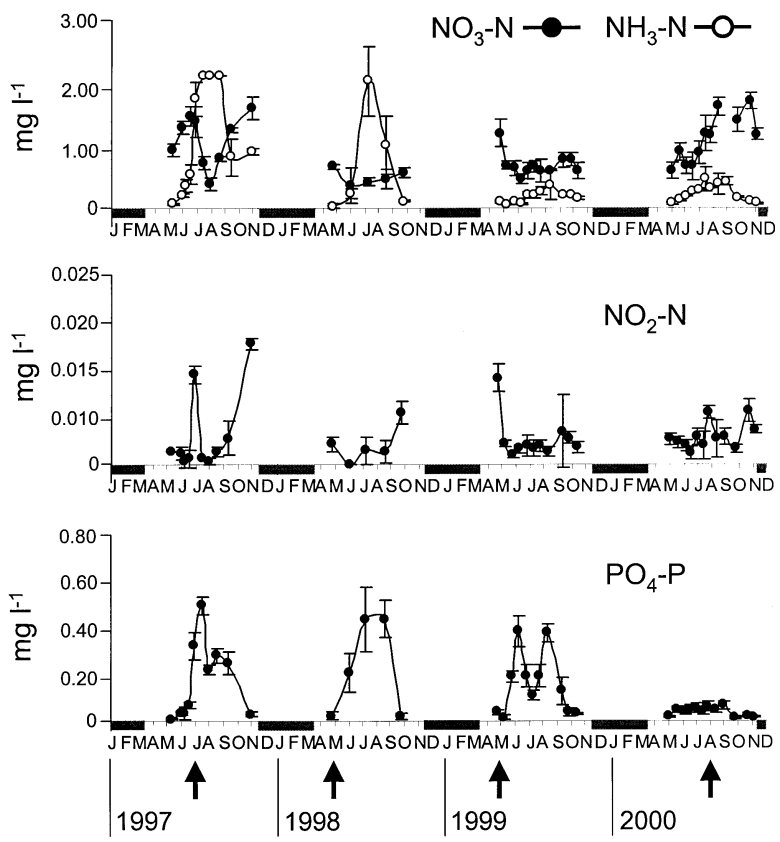

Fig. 3 Temporal patterns of NO3-N, NH3-N, NO2-N and PO4-P (mean \pm 2 SE) from 1997 to 2000. During ice-covered period (grey thick line), the lake was not sampled. Arrows indicate the observed fish kill events.

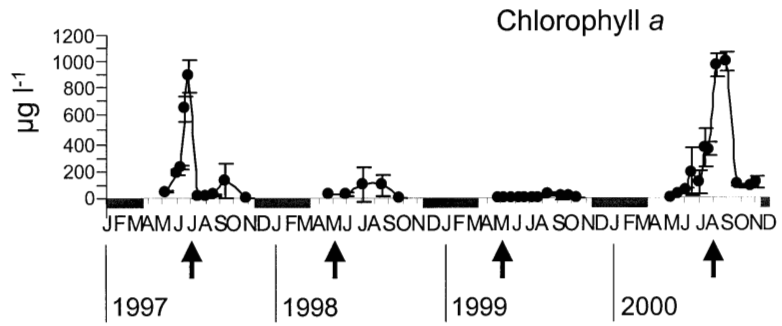

Fig. 4 Temporal pattern of phytoplanktonic chlorophyll $a$ (mean \pm 2SE) from 1997 to 2000. During ice-covered period (grey thick line), the lake was not sampled. Arrows indicate the observed fish kill events.

tion. In 2000 the minimum water depth was higher than previous years suggesting heavier, or a higher number, of run-off events and a possible larger draining of livestock dejections into the lake.

In eutrophic shallow lakes, phosphorus availability is mainly determined by internal loading from sediments (Scheffer 1998). Since macrophyte presence and high $\mathrm{pH}$ values may increase sediment phosphorus release (Granéli 1999, Stephen et al. 1997), the detected $\mathrm{pH}$ values (Fig. 2) and the estimated macrophyte cover (Table 2) suggest internal loading to have been significantly high in Lake Duchessa. In 2000 a $90 \%$ macrophyte cover and an annual $\mathrm{pH}$ mean of $9.8( \pm$ 0.3 ) were still favorable for a high phosphorus loading from sediments. Seemingly, the low SRP concentration observed in this year was possible due to an increased consumption by primary producers as we detected a high phytoplankton standing crop in the same year (Fig. 4)

The eutrophic conditions of Lake Duchessa possibly caused the observed natural fish kills. In particular the ammonia concentrations along with the $\mathrm{pH}$ values detected in the lake easily contributed to the large fish kill observed in the summer of 1997 and 2000. At pH $>9.5$ ammonia is present as $\mathrm{NH}_{4}{ }^{+}$or $\mathrm{NH}_{4} \mathrm{OH}$ (lethal to fish) with a ratio of 1:1 (Hutchinson 1957) and in lakes with these conditions «summer fish kills» are generally expected (Kann \& Smith 1999). On the other hand in May of 1998 and in May of 1999 we probably observed the effects of two «winter fish kills». In ice covered eutrophic shallow lakes heavy fish kills occur as consequence of the decomposition of organic matter accumulated in the bottom which in turn deplete oxygen in the water (Greenbank 1945).

Mountain lakes communities usually show low diversity because of the harsh environment and the low colonization rate of remote areas where they are situated (Rautio 1998, Fjellheim et al. 2000, Mc Naught et al. 2000). The extreme water depth $(3.5 \mathrm{~m}-0.2 \mathrm{~m})$ and high temperature $\left(22.4{ }^{\circ} \mathrm{C}-0.6^{\circ} \mathrm{C}\right)$ excursions of Lake Duchessa probably cause some expected families to be completely missing in its macrobenthic assemblage. The absence of mollusk from the lake was noticeable as they have been found in other similar lakes (Solimini et al. 2000, Ruggiero et al. 2001). However, this could be explained by the presence of the large tench population as $T$. tinca can show specialized foraging for mollusk (Brönmark 1994). Macrophyte cover, which increases invertebrate habitat diversity by providing food, substrate and refuge (Diehl \& Kornijow 1997), ensured the presence of all the feeding groups. Macrophytes found in the lake belong to the Potamogeton pectinatus - Myriophyllum spicatum community described in Great Britain (Rodwell et al. 1995, p. 59), they are usually found in turbid and eutrophic conditions (Hootsman et al. 1996, Moss et al. 1997, Scheffer 1998). However, macrophyte colonization of Lake Duchessa in the past was likely favored by the low water level periods (Blindow 1992). In the zooplankton as- 
semblage the number of species was low but comparable with those of other mountain lakes (King et al. 1996, Angeli et al. 2002). The presence in the samples of fast swimmers such as copepods indicate this method not to be selective for some particular species (i.e. slow swimmers). The absence of rotifers could be explained by the size of plankton net used even if some authors found low density of rotifers with values of $\mathrm{pH}$ and conductivity (affecting rotifers life cycle) similar to those measured in this study (Morales-Baquero et al. 1989, Arnott \& Vanni 1993).

In Lake Duchessa nutrient availability ensured a potentially high algal production. In 1997 phytoplankton biomass dropped in the summer giving rise to a clear water phase which was observed during the rest of the year. This opposes the expected trend of shallow eutrophic lakes maintaining high biomass throughout the year (Sommer et al. 1986, Scheffer 1991, Scheffer 1998). The phytoplankton biomass drop coincided with a reduction in the density of zooplanktivorous fish suggesting an increase in zooplankton grazing of algae played the major role (Jeppesen et al. 1990, Jeppesen et al. 1991, Carvalho 1994). Accordingly, the trophic cascade hypothesis states that deviations from potential productivity could be due to food web effects (Shapiro \& Wright 1984, Carpenter \& Kitchell 1993). From this, it is possible to deduce that the 1997 fish kill possibly caused the observed phytoplankton collapse and corresponding clear water phase, as reported in other cases of natural fish kills (Vanni et al. 1990, Jeppesen et al. 1998).

Clear water periods are usually short in eutrophic shallow lakes (Deneke \& Nixdorf 1999), but in Lake Duchessa phytoplanktonic biomass remained below potential values throughout 1998 and 1999 and clear water conditions were maintained throughout. It has been shown that macrophytes promote and stabilize clear water conditions keeping phytoplankton biomass low by (i) offering refuge to zooplankton species, (ii) competing with algae for resources (iii) releasing allopathic substances (Jeppesen et al. 1997, Mjelde \& Faafeng 1997, Scheffer 1998, Bertolo et al. 1999, Strand \& Weisner 2001, Burks et al. 2001). Accordingly, it is possible that macrophytes maintained the clear water conditions for the two years in Lake Duchessa, as already shown for other lakes (Van den Berg et al. 1997, Scheffer 1998). Leaf canopies of $P$. pectinatus and $M$. spicatum, developing throughout the water column, had the potential to affect phytoplankton production by reducing both light and space availability. In 2000, with macrophytes still covering $90 \%$ of the lake area, algae biomass yield reached the potential values sugges- ting some other key mechanism maintaining the clear water conditions in the previous two years. T. tinca is known to heavily predate on zooplankton (Brönmark 1994, Giles et al. 1990, Ranta \& Nuutinen 1984). Accordingly, a possible explanation would be that the macrophyte «refuge effect» for zooplankton, which is known to be scarce at high fish densities (Schriver et al. 1995, Stephen et al. 1998), became important after the large fish-kill of 1997 reduced tench population while it was scarce again in 2000 as consequence of the possible increase in tench population density after a three-year recruitment.

\section{Conclusion}

Lake Duchessa shows some limnological aspects proper to lowland degraded lakes, this being due to livestock grazing in the watershed and watering in the lake. In particular phytoplankton biomass and turbidity are comparable to those of the most eutrophic situations commonly described in the literature (i.e. tropical ponds, Sarnelle et al. 1998). On the other hand, the data shown highlight the possible processes of obtaining clear water conditions in such highly eutrophic situations. Evidences indicate that the observed drop in phytoplankton biomass and the subsequent improvement in water transparency were possibly due to a drastic reduction of the fish density. Seemingly, the presence of a well developed macrophyte cover could explain the decrease of nitrogen in the water column and the maintenance of clear water conditions for two years. Since Lake Duchessa conditions are emblematic of the generalized situation of lakes and ponds situated at high altitude in central Apennines (Solimini et al. 2000, Ruggiero et al. 2001, Ruggiero et al. 2003a,b), these ecological processes require addressing as promising applied research subjects. Accordingly, we suggest that future investigations should incorporate the manipulation of fish and macrophyte populations to set the effective management strategies to restore and maintain these unique ecosystems.

\section{Acknowledgements}

M. Anello and A. Mutchlechner greatly helped during filed work and laboratory analyses. We thank O. Ferrara, and M. Iberite for determination of zooplankton and macrophyte taxa respectively. We thank E. Jeppesen and A. Cattaneo for comments on an early draft. N. Elwood made useful suggestions to improve the manuscript. We thank an anonymous referee for the valuable review of the manus- 
cript. Riserva Parziale Montagne della Duchessa supported field activities and provided data of the 2002 monitoring program. This work was funded by three grants, two from C.N.R. and one from University of Rome «Tor Vergata» (Progetto Giovani Ricercatori) to A. Ruggiero and by a M.U.R.S.T. grant to G. Carchini (program: Biologia della fauna delle acque dolci e dei suoli).

This research was also funded by a grant of Instituto Nazionale della Montagna to A.G. Solimini, «Uso sostenibile della risorsa acqua nei parchi naturali montani dell'Appennino Centrale : Studio pilota sulla relazione tra attività agropastorali e la diversità degli invertebrati delle pozze d'alpeggio». (Grant : Agenzia 2002, gruppo 3 cod. 191).

\section{References}

Angeli N., Cantonati M. \& Rossetti G. 2002. - Lo zooplancton. Pages 153-187 in I laghi del Parco Naturale Adamello-Brenta. Cantonati M., Tolotti M. \& Lazzara M. (eds). Parco Naturale Adamello-Brenta \& Museo Tridentino di Scienze Naturali, Strembo (TN).

Arnott S. E. \& Vanni M. J. 1993. - Zooplankton assemblages in fishless bog lakes: influence of biotic and abiotic factors. Ecology, 74 2361-2380

Baldi E. 1942. - Le pozze delle Viotte sul monte Bondone. Studi Trent. Sci. Nat., 23, 71-81.

Barko J. W. \& James W. F. 1997. - Effects of submerged aquatic macrophytes on nutrient dynamics, sedimentation, and resuspension. Pages 197-214 in The structuring role of submerged macrophytes in lakes. Jeppesen E., Sondergaard M., Sondergaard M. \& Christoffersen K. (eds). Springer-Verlag, New York, USA

Beaty M. H. \& Parker B. C. 1996. - Response of phytoplankton primary productivity to nutrient enrichment at Mountain Lake, Virginia. J. Freshwat. Ecol., 11, 421-431.

Bertolo A., Lacroix G., Lescher-Moutoué F. \& Sala S. 1999. - Effects of physical refuges on fish-plankton interactions. Freshwat. Biol., 41, 795-808.

Blindow I. 1992. - Long- and short-term dynamics of submerged macrophytes in two shallow eutrophic lakes. Freshwat. Biol., 28 , 15-27.

Brönmark C. 1994. - Effects of tench and perch on interactions in a freshwater, benthic food chain. Ecology, 75, 1818-1828.

Burns L. C., Stevens R. J., Smith R. V. \& Cooper J. E. 1995. - The occurrence and possible sources of nitrite in a grazed, fertilized, grassland soil. Soil Biol. Biochem, 27, 47-59.

Burks R. L., Jeppesen E. \& Lodge D. M. 2001. - Littoral zone structures as Daphnia refugia against fish predators. Limnol. Oceanogr., 46, 230-237.

Carpenter S. R. \& Kitchell J. F. 1993. - The trophic cascade in lakes. Cambridge University Press, Cambridge, $385 \mathrm{p}$.

Carvalho L. 1994. - Top-down control of phytoplankton in a shallow hypertrophic lake: Little Mere (England). Hydrobiologia, 275/276, 53-63.

Cianficconi F., Moretti G. \& Castellani M. 1994. - La vita nelle «pozze d'alpeggio» dell' Appennino centrale: i Tricotteri, Atti XVII Congresso Nazionale Italiano di Entomologia , 417-422.

Collinson N. H., Biggs J., Corfield A., Hodson M. J., Walker D., Whitfield M. \& Williams P. J. 1995. - Temporary and permanent ponds: an assessment of the effects of drying out on the conservation value of aquatic macroinvertebrate communities. Biol. Conserv., 74, 125-133.

Colliver B. B. \& Stephenson T. 2000. - Production of nitrogen oxide and dinitrogen oxide by autotrophic nitrifiers. Biotechnology Advances, $18,219-232$.
Deneke R. \& Nixdorf B. 1999. - On the occurrence of clear-wate phases in relation to shallowness and trophic state: a comparative study. Hydrobiologia, 408/409, 252-262.

Diehl S. \& Kornijow R. 1997. - Influence of submerged macrophytes on trophic interactions among fish and macroinvertebrates. Pages 24-46 in The structuring role of submerged macrophytes in lakes. Jeppesen E., Sondergaard M. \& Christoffersen K. (eds). Springer-Verlag, New York, USA.

Di Giorgio M. \& Zuppa A. M. 1996. - Macrobenthos of the Gran Sasso small lakes and of the Nora sources (Preliminary note). Pages 284-289 in Monitoraggio Biologico del Gran Sasso. Cicolani B. (ed). Andromeda Editrice, TE, Italy.

Di Sabatino A., Cicolani B. \& Gerecke R. 2003. - Biodiversity and distribution of water mites (Acari, Hydrachnidia) in spring habitats. Freshwat. Biol., 48, 2163-2173.

Duff K. E., Laing T. E., Smol J. P. \& Lean D. R. S. 1999. - Limnological characteristics of lakes located across arctic treeline in northern Russia. Hydrobiologia, 391, 205-222.

Eriksson P. G. \& Weisner S. E. B. 1999. - An experimental study on effects of submersed macrophytes on nitrification and denitrification in ammonium-rich aquatic systems. Limnol. Oceanogr., 44 1993-1999.

Fjellheim A., Boggero A., Halvorsen G. A., Nocentini A. M., Rieradevall M., Raddum G. \& Oyvind A. S. 2000. - Distribution of benthic invertebrates in relation to environmental factors. A study of European remote Alpine lake ecosystems. Verh. internat. Verein. Limnol., 27, 484-488.

Gee J. H. R. \& Duigan C. A. 1993. - The Limnology of Lac d'Ifni (High Atlas Mountains, Morocco), an unusually productive mountain lake. Freshwat. Biol., 30, 447-462.

Giles N., Street M. \& Wright R. M. 1990. - Diet composition and prey preference of tench, Tinca tinca (L.) common bream, Abramis brama (L.), perch, Perca fluviatilis L. and Roach, Rutilus rutilus (L.), in two contrasting gravel pit lakes: potential trophic overlap with wildfowl. J. Fish Biol., 37, 945-957.

GranÈli W. 1999. - Internal phosphorus loading in Lake Ringsjön. Hydrobiologia, 404, 19-26.

Greenbank J. 1945. - Limnological conditions in ice-covered lakes, especially as related to winter-kill of fish. Ecol. Monogr., 15, 343392.

Hootsmans M. J. M., Drovandi A. A., Soto Perez N. \& Wiegman F. 1996. - Photosynthetic plasticity in Potamogeton pectinatus $\mathrm{L}$. from Argentina: strategies to survive adverse light conditions. Hydrobiologia, 340, 1-5.

Hutchinson G. E. 1957. - A treatise on Limnology. I. Wiley, New York, $1015 \mathrm{p}$

Jeppesen E., Sondergaard M., Sortkjaer O., Mortensen E. \& Kristensen P. 1990. - Interactions between phytoplankton, zooplankton and fish in a shallow, hypertrophic lake: a study of phytoplankton collapses in Lake Sobygard, Denmark. Hydrobiologia, 191, 149164.

Jeppesen E, Kristensen P., Jensen J. P., Sondergaard M., Mortensen E. \& Lauridsen T. 1991. - Recovery resilience following a reduction in external phosphorus loading of shallow, eutrophic Danish lakes: duration, regulating factors and methods for overcoming resilience. Mem. Ist. Ital. Idrobiol., 48, 127-148.

Jeppesen E., Jensen J. P., Sondergaard M., Lauridsen T., Pedersen L. J. \& Jensen L. 1997. - Top-down control in freshwater lakes: the role of nutrient state, submerged macrophytes and water depth. Hydrobiologia, 342/343, 151-164

Jeppesen E., Sondergaard M., Jensen J. P., Mortensen E., Hansen A. M. \& Jorgensen T. 1998. - Cascading trophic interactions from fish to bacteria and nutrients after reduced sewage loading: an 18years study of a shallow hypertrophic lake. Ecosystems, 1, 250267. 
Kann J. \& Smith V. H. 1999. - Estimating the probability of exceeding elevated $\mathrm{pH}$ values critical to fish populations in a hypertrophic lake. Can. J. Fish Aquat. Sci., 56, 2262-2270.

King J.L., Simovich M. A. \& Brusca R. C. 1996. - Species richness, endemism and ecology of crustacean assemblages in northern $\mathrm{Ca}$ lifornia vernal pools. Hydrobiologia, 328, 85-116.

Kleeberg A. \& Kozerski H.P. 1997. - Phosphorus release in Lake Grofler $M_{s}$ ggelsee and its implications for lake restoration. $\mathrm{Hy}$ drobiologia, 342/343, 9-26.

Kopacek J., Stuchlik E., Straskrabova V. \& Psenakova P. 2000. Factors governing nutrient status of mountain lakes in the Tatra Mountains. Freshwat. Biol., 43, 369-383.

Larson G. L., Wones A., McIntire C. D. \& Samora B. 1994. - Integrating limnological characteristics of high mountain lakes into the landscape of a natural area. Environ. Manage., 18, 871-888.

Larson G. L., Mclntire C. D., Karnaugh-Thomas E. \& HawkinsHoffman C. 1995. - Limnology of isolated and connected highmountain lakes in Olympic National Park, Washington state, USA. Arch. Hydrobiol., 134, 75-92.

Leu H.-G., Lee C.-D., Ouyang C. F. \& Tseng H.T. 1998. - Effects of organic matter on the conversion rates of nitrogenous compounds in a channel reactor under various flow conditions. Wat. Res., 32, 891-899.

Liboriussen L. \& Jeppesen E. 2003. - Temporal dynamics in epipelic, pelagic and epiphytic algal production in a clear and a turbid shallow lake. Freshwat. Biol., 48, 418-431.

Margaritora F. G. \& Usai M. C. 1983. - Osservazioni faunistico-ecologiche su un laghetto d'alta quota dell'Appennino Abruzzese: Il Lago di Campo Felice. Riv. Idrobiol., 22, 159-167.

McNaught A. S., Pavlik D. \& Schindler D. W. 2000. - Patterns of zooplankton biodiversity in the mountain lakes of Banff National Park, Canada. Verh. internat. Verein. Limnol., 27, 494-499.

Meijer M. L., Jeppesen E., van Donk E., Moss B., Scheffer M., Lammens E., van Nes E., van Berkum J. A., de Jong G. L., Faafeng B. A. \& Jensen J. P. 1994. - Long-term responses to fish-stock reduction in small shallow lakes: interpretation of five-year results of four biomanipulation cases in The Netherlands and Denmark. Hydrobiologia, 275/276, 457-466.

Mjelde M. \& Faafeng B. A. 1997. - Ceratophyllum demersum hampers phytoplankton development in some small Norwegian lakes over a wide range of phosphorus concentration and geographical latitude. Freshwat. Biol., 37, 355-365.

Morales-Baquero R., Cruz-Pizarro L. \& Carrillo P. 1989. - Patterns in the composition of the rotifer communities from high mountain lakes and ponds in Sierra Nevada (Spain). Hydrobiologia, $186 / 187,215-221$.

Mosello R., Boggero A. \& Marchetto A. 1996. - Ricerche sull'inquinamento dei laghi remoti in Europa: il caso dei laghi Paione (Alpi Centrali, Val D'Ossola). Soc. Ital. Ecol. Atti, 17, 95-98.

Moss B., Madgwick J. \& Phillips G. 1997. - A guide to the restoration of nutrient-enriched shallow lakes. WW Hawes, UK, 180 p.

Mura G. 1987. - Osservazioni faunistico-ecologiche su di un gruppo di pozze di alpeggio dei Monti Reatini. Riv. Idrobiol., 26, 123130.

Mura G. 1993. - Habitat and life history of Chirocephalus macrchesonii Ruffo \& Vesentini 1957, an endemic fairy shrimp from monti Sibillini, central Italy. Riv. Idrobiol., 32, 73-104.

Mura G. 1996. - Observation on the biology of the rare Branchipus visnyai Kertesz 1956 (Crustacea Anostraca) from Monti Reatini (Latium, central Italy). Hydrobiologia, 325, 239-254.

Mura G., Fancello G. \& Di Giuseppe S. 2003. - Adaptive strategies in populations of Chirocephalus diaphanus (Crustacea, Anostraca) from temporary waters in the Reatine Apennines (Central Ita1y). J. Limnol., 62, 35-40.
Nauwerck A. 1994. - A survey on water chemistry and plankton in high mountain lakes in northern Swedish Lapland. Hydrobiologia, 274, 91-100.

Petriccione B. 1993. - Flora e vegetazione del massiccio del monte Velino (Appennino centrale). Collana Verde n. 92, Ministero delle Risorse Agricole, Alimentari e Forestali, 261 p.

Portielje R. \& Rijsdijk R. E. 2003. - Stochastic modelling of nutrient loading and lake ecosystem response in relation to submerged macrophytes and benthivorous fish. Freshwat. Biol., 48, 741-755.

Ranta E. \& Nuutinen V. 1984. - Zooplankton predation by rock-pool fish (Tinca tinca L. and Pungitus pungitus): an experimental study. Ann. Zool. Fennici, 21, 441-449.

Rautio M. 1998. - Community structure of crustacean zooplankton in subarctic ponds - effects of altitude and physical heterogeneity. Ecography, 21, 327-335.

Rioual P. 2002. - Limnological characteristics of 25 lakes of the French Massif Central. Ann. Limnol. - Int. J. Lim., 38, 311-327.

Rodwell J. S., Pigott C. D., Ratcliffe D. A., Malloch A. J. C., Birks H. J. B., Proctor M. C. F., Shimwell D. W., Huntley J. P., Radford E., Wigginton M. J. \& Wilkins P. 1995. - British Plant Communities, 4 Aquatic communities, swamps and tall-herb fens. Cambridge University Press, 283 p.

Ruggiero A., Solimini A. G., Mutschlechner A., Anello M. \& Carchini G. 2001. - Aspetti limnologici del Lago di Racollo (1568 m s.l.m.), Campo Imperatore (AQ). Studi Trent. Sci. Nat., Acta Biologica, 78, 173-180.

Ruggiero A., Solimini A. G. \& Carchini G. 2003a. - Nutrient and chlorophyll a temporal patterns in eutrophic mountain ponds with contrasting macrophyte coverage. Hydrobiologia, 506-509, $657-$ 663.

Ruggiero A., Solimini A. G. \& Carchini G. 2003b. - Pratica dell'alpeggio e conservazione ambientale negli stagni montani dell'Appennino Centrale. In Atti del convegno nazionale Conservazione dell'ambiente e rischio idrogeologico. L. Ubertini (ed), 706 p.

Sarnelle O., Cooper S. D., Weiseman S. \& Mavuti K. M. 1998. - The relationship between nutrients and trophic-level biomass in turbid tropical ponds. Freshwat. Biol., 40, 65-75.

Scheffer M. 1991. - Fish and nutrients interplay determines algal biomass: a minimal model. Oikos, 62, 271-282.

Scheffer M. 1998. - Ecology of Shallow Lakes. Chapman and Hall, London, $357 \mathrm{p}$.

Schriver P., Bogestrand J., Jeppesen E. \& Sondergaard M. 1995. Impact of submerged macrophytes on fish-zooplankton-phytoplankton interactions: large-scale enclosure experiments in a shallow eutrophic lake. Freshwat. Biol., 33, 255-270.

Shapiro J. \& Wrigth D. I. 1984. - Lake restoration by biomanipulation: Round Lake, Minnesota, the first two years. Freshwat. Biol., 14, 371-383.

Solimini A. G., Ruggiero A., Anello M., Mutschlechner A. \& Carchini G. 2000. - The benthic community structure in mountain ponds affected by livestock watering in nature reserves of Central Italy. Verh. internat. Verein. Limnol., 27, 501-505.

Sommer U., Gliwicz Z. M., Lampert W. \& Duncan A. 1986. - The PEG-model of seasonal succession of planktonic events in fresh waters. Arch. Hydrobiol., 106, 433-471.

Stella E. 1988. - Contribution to the taxonomy and distribution of Cyclops abyssorum Sars (Crustacea, Copepoda) in several lakes and ponds of central Italy. Hydrobiologia, 167/168, 381-385.

Stephen D., Moss B. \& Phillips G. 1998. - The relative importance of top-down and bottom-up control of phytoplankton in a shallow macrophyte-dominated lake. Freshwat. Biol., 39, 699-713.

Stephen D., Moss B. \& Phillips G. 1997. - Do macrophytes increase sediment phosphorus release? Hydrobiologia, 242/243, 27-34. 
Strand J. A. \& Weisner S. E. B. 2001. - Dynamics of submerged macrophyte populations in response to biomanipulation. Freshwat. Biol., 46, 1397-1408.

Threlkeld S. T. 1994. - Benthic-pelagic interactions in shallow water columns: an experimentalist's perspective. Hydrobiologia 275/276, 293-300.

Van den Berg M. S., Coops H., Meijer M.-L., Scheffer M. \& Simons J. 1997. - Clear water associated to with a dense Chara vegetation in the shallow and turbid lake Veluwemeer, The Netherlands. Pages 339-352 in The structuring role of submerged macrophytes in lakes. Jeppesen E., S-ndergaard M., Sondergaard M. \& Christoffersen K. (eds). Springer-Verlag, New York, USA.

Van Luijn F., Boers P. C. M., Lijklema L. \& Sweerts J.-P.-R. A 1999. - Nitrogen fluxes and processes in sandy and muddy sediments from a shallow eutrophic lake. Wat. Res., 33, 33-42.
Vanni M. J., Luecke C., Kitchell J. F. \& Magnuson J. J. 1990. - Effects of planktivorous fish mass mortality on the plankton community of Lake Mendota, Wisconsin: implications for biomanipulation. Hydrobiologia, 200/201, 329-336.

Vass K. K., Wanganeo A., Raina H. S., Zutshi D. P. \& Wanganeo R. 1989. - Summer limnology and fisheries of high mountain lakes of Kashmir Himalayas. Arch. Hydrobiol., 114, 603-619.

Viaroli P., Ferrari I., Paris G., Rossetti G. \& Menozzi P. 1994. - Limnological research on northern Apennine lakes (Italy) in relation to eutrophication and acidification risk. Hydrobiologia, 274, 155162.

Wetzel R. G. \& Likens G. E. 1991. - Limnological Analyses. Springer-Verlag, New York, 391 p.

Wetzel R. G. 1983. - Limnology. Saunders College Publishing, USA, 767 p. 